\title{
Can the Caper (Capparis spinosa L.) Still Be Considered a Difficult-to-Propagate Crop?
}

\author{
Francesco Sottile $^{1, * \mathbb{D}}$, Chiara Caltagirone ${ }^{1}$, Cristiana Peano $^{2} \mathbb{D}$, Maria Beatrice Del Signore ${ }^{3}$ and Ettore Barone ${ }^{3} \mathbb{D}$ \\ 1 Department of Architecture, University of Palermo, Viale delle Scienze, Building 14, \\ 90128 Palermo, Italy; chiaracaltagirone@gmail.com \\ 2 Department of Agricultural, Forestry and Food Sciences, University of Turin, Largo Braccini 1, \\ Grugliasco (To), 10129 Turin, Italy; cristiana.peano@unito.it \\ 3 Department of Agricultural, Forestry and Food Sciences, University of Palermo, Viale delle Scienze, \\ Building 4, 90129 Palermo, Italy; beatricedelsignore@gmail.com (M.B.D.S.); ettore.barone@unipa.it (E.B.) \\ * Correspondence: francesco.sottile@unipa.it; Tel.: +39-09123861200
}

Citation: Sottile, F.; Caltagirone, C.; Peano, C.; Del Signore, M.B.; Barone, E. Can the Caper (Capparis spinosa L.) Still Be Considered a Difficult-toPropagate Crop? Horticulturae 2021, 7, 316. https://doi.org/10.3390/ horticulturae7090316

Academic Editor: Douglas

D. Archbold

Received: 22 August 2021

Accepted: 13 September 2021

Published: 16 September 2021

Publisher's Note: MDPI stays neutral with regard to jurisdictional claims in published maps and institutional affiliations.

Copyright: (c) 2021 by the authors. Licensee MDPI, Basel, Switzerland. This article is an open access article distributed under the terms and conditions of the Creative Commons Attribution (CC BY) license (https:// creativecommons.org/licenses/by/ $4.0 /)$

\begin{abstract}
As a perennial xerophytic shrub, characterized by plesiomorphic features, the caper (Capparis spinosa L.) is naturally spread throughout the Mediterranean basin and occupies an important ecological role, as well as an economic one, in traditional and specialized systems for commercial production. This species, in spite of its wide diffusion, is currently considered at risk of genetic erosion, mainly due to overgrazing and overharvesting for domestic uses and for trade. This situation is made more serious because of the lack of efficient propagation techniques, determining the caper as a "difficult-to-propagate species". In this review, we report the main available sexual and vegetative propagation techniques with the aim of assessing whether, and to what extent, this criticality is still true for caper as a horticultural crop. In terms of seed propagation, germination rates have generally been considered quite low or unsatisfactory, and are also affected by hybridization phenomena that are likely to occur among both the wild and cultivated forms. The seeds show a physiological dormancy that can be lowered by adopting hormonal treatments, but in situ germination remains a critical phase. Vegetative propagation appears quite effective, mostly as related to in vitro techniques that allow caper cultivation that is no longer affected by propagation for an economic dissemination of the species in more intensive orchards. The research needs for Caper spinosa L. as a horticultural crop, especially in the field of genetic improvement and breeding, are also underlined.
\end{abstract}

Keywords: Capparis spinosa; seed propagation; vegetative propagation; in vitro propagation; Mediterranean basin

\section{Introduction}

The caper (Capparis spinosa L.) is one of about 250 species of the genus of xerotropical origin belonging to the family Capparaceae, widely distributed from the Mediterranean eastwards to Central and Southeast Asia, Australia and Oceania [1]. This perennial xerophytic shrub, characterized by plesiomorphic features, is naturally spread throughout the Mediterranean basin, composing part of the Mediterranean Maquis together with other species [2-4], participating with two subspecies, C. spinosa subsp. spinosa and C. spinosa subsp. rupestris [5]. It is also widely diffused in cultivated form, especially in Southern Europe (Italy, Spain and Greece), in North Africa (Tunisia, Morocco and Egypt) and in the Middle East (Syria and Turkey), in traditional and specialized systems for commercial production of pickled, in salt or vinegar, immature flower buds (the caper of commerce), unripe fruits (caper berries) and tender shoots, or as an ornament. The capers for commerce and the other related products have been used since ancient times [6] for food or as a condiment $[7,8]$, as well as in ethnopharmacology, medicine and cosmetics, due to a number of bioactive compounds with beneficial properties and effects [9-15]. However, most of the caper products available in the international market rely largely on the wild plants, as 
cultivation is not able to meet the thriving market demand [6]. In Italy, caper cultivation, based upon local selections or biotypes [16] of C. spinosa L., domesticated in situ from subsp. rupestris [17], is concentrated in the small islands around Sicily (mostly Pantelleria and the Aeolian Islands Salina, Lipari and Filicudi). In these Sicilian areas, the species plays a significant socio-economical role [18,19] and was awarded in 1996 with the designation of UE "Protected Geographical Indication" (PGI) for the caper grown on the island of Pantelleria (Figure 1), and more recently (2020), for that on the Aeolian archipelago, by EU "Protected Designation of Origin" (PDO-IT-20A02570), under the denomination of "Cappero delle Isole Eolie Dop". On the Aeolian island of Salina (Figure 2), a Slow Food Presidium has been active for many years, with the aim of preserving a heritage of cultural and agronomic knowledge linked to the island's history and the resilience of its heroic agriculture [20].

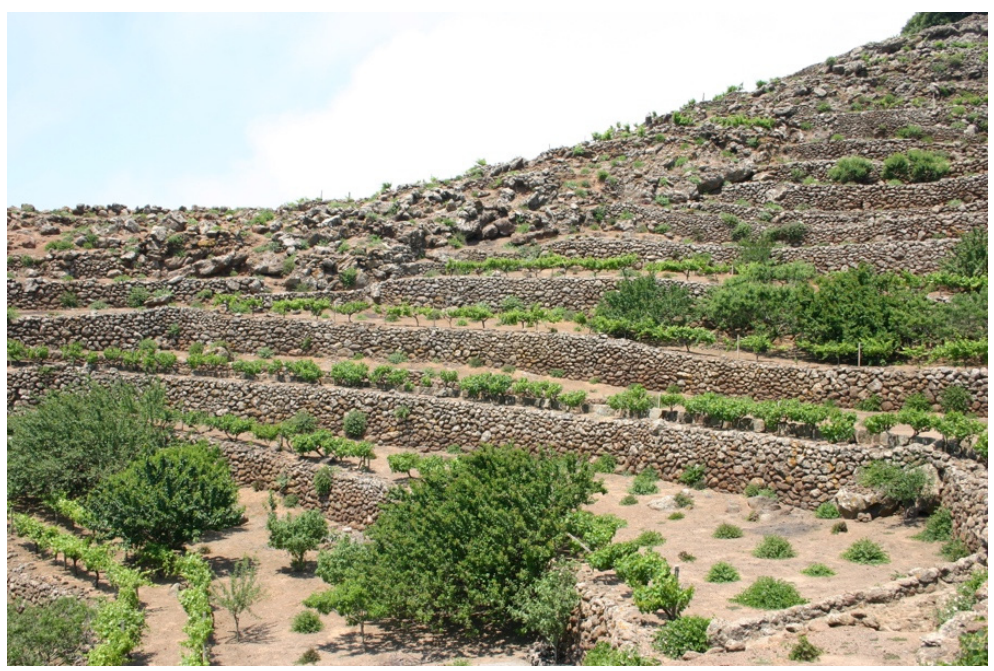

Figure 1. Traditional caper orchard on the island of Pantelleria, where sloped lands in ancient times were managed in order to obtain comfortable terraces.

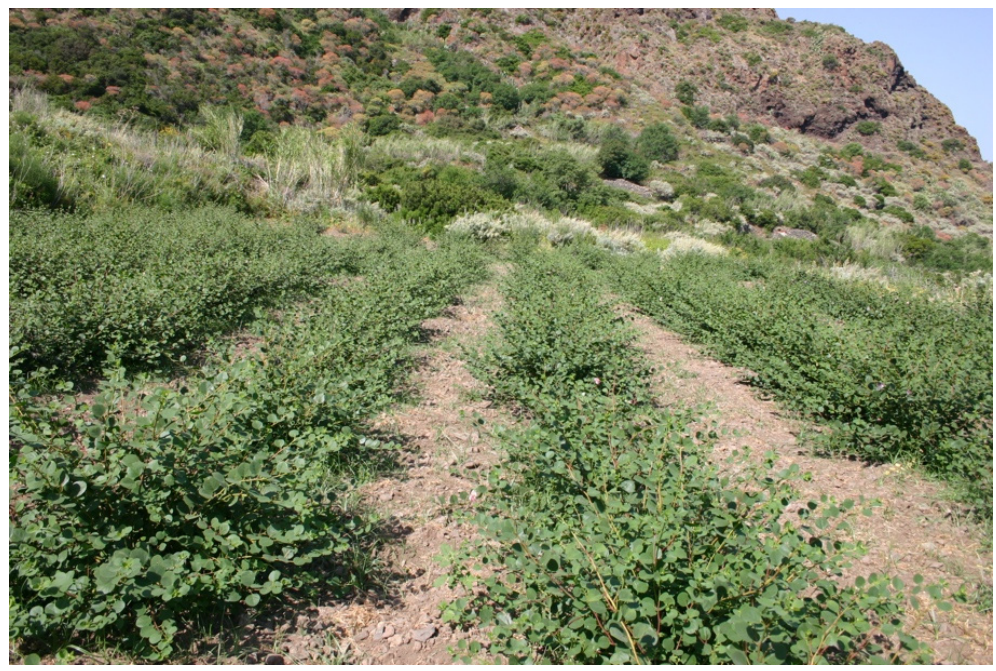

Figure 2. Intensive caper orchard on the island of Salina.

Well adapted to harsh environmental conditions [21], due to its xerophytic habit and its deep root system [22,23], its exceptional photosynthetic characteristics, maintained under high irradiance and temperature without damage symptoms [24], and its adaptation to poor soils [25], C. spinosa L., could, therefore, significantly contribute to the development of local, marginal areas [21], especially those of small islands. Additionally, caper may help preserve the equilibrium of fragile arid and semiarid ecosystems [26] by reducing the soil erosion 
hazard [27], by enhancing landscape sustainability, water conservation [28], rehabilitation of rangelands and desert lands and dune stabilization $[29,30]$ and by preventing fires from spreading [31]. Altogether, these features make this species of potential strategic interest as an adaptive crop in a climate change context [32].

Nevertheless, despite its natural diffusion and cultivation, Capparis spinosa L., as a Wild Harvested Plant (WHP), is currently considered at risk of genetic erosion, mainly due to overgrazing and overharvesting for domestic uses and for trade. In fact, it has been included in the IUCN Red List of Threatened Species [33], even if assessed globally as "Least Concern", and as an endangered species, among the Neglected and Underutilized plant Species (NUS) [19,34].

One of the major constraints, both in the cultivation and in the conservation of WHP or NUS species in the Mediterranean region, is generally represented by the lack of modern, adequate and efficient propagation techniques [35]. Caper has long been considered as a "difficult-to-propagate species", mostly because of the poor seed germination rate generally observed [36], together with the heterogenous population obtained from seed $[8,29]$ and the frequent erratic response of rooting $[37,38]$.

The question that will be discussed in the present review is, therefore, whether, and to what extent, this reputation is still true for caper as a horticultural crop. Here, we describe the main available propagation techniques and the main factors influencing the results by reviewing the most relevant literature regarding both sexual and vegetative caper propagation. The underlying hypothesis is that the caper industry is, from an agronomic point of view, still in its infancy and that, therefore, some of the "traditional" propagation systems still widely utilized may be no longer valid for modern and specialized caper cultivation.

\section{Seed Propagation}

Caper propagation in natural habits is ensured by seed dispersal exerted by several animals attracted by the juicy flesh of caperberries, such as lizards, ants, wasps, birds, rats and rabbits [39-42] which transport and release the undigested seeds, thus enhancing the permeability of the seed coats, and ultimately increasing the seed germination rate. These plants obtained from seed exhibit a high degree of heterogeneity in morphophysiological traits that are conducive to species adaptation and resilience in wild habitats, and may be of extreme interest for breeding purposes, but decidedly not for the agronomic exigence of homogeneity. Nevertheless, according to Chedraoui [21], seed germination is the method of propagation most utilized for caper plant cultivation, and some authors even report [18] that these seedling plants are considered by the farmers "homogeneous enough for the purposes of quality and quantity requirements of the crop". As a matter of fact, seed propagation, also favored by the caper seedlings' short juvenile period and the high number of seeds contained in each fruit (up to 400), is still commonly used in Pantelleria for caper cultivation, although using some farmers' selected lines [16,38], as well as in many other countries. Furthermore, it should be noted that caper seeds, if well stored (i.e., $4-7^{\circ} \mathrm{C}$ and low relative humidity), can maintain their germination potential for about 2 years $[43,44]$ or even more than 3 years $[45,46]$ before gradually decreasing.

The seed propagation techniques used in Pantelleria [38] include elemental operations and are carried out in small seedbeds arranged outdoors, without either any disinfection or pre-germination seed treatment or regular irrigation. A good part of the seed population germinates 25-50 days after sowing; however, it is not uncommon to record germination after one or two years. Seedling transplanting is performed during the following winter.

On the other hand, in Spain (Figure 3), nursery seed propagation includes seed stratification in sand, followed by sowing in raised beds in the second half of April to the beginning of May, using 1.5 or $2 \mathrm{~g}$ of pre-germinated seeds per linear meter, corresponding to approximately 250-330 seeds $\mathrm{m}^{-1}$ [37]. Seeds lots are collected in August-September from ripe, opened fruits, when flesh color is dark red and seed color is dark brown. They are then rinsed with water, separated from the flesh, and gently dried in the shade before stratification to soften the seed covering. This is carried out after a fungicide treatment in 
stratified, opportunely moistened sand layers, each $2-4 \mathrm{~cm}$ high. This process takes 25 to 50 days and generally leads to a $30-40 \%$ pre-germination rate. The full emergence of the plantlets (45-50 out of the initial 250-330 pre-germinated seeds) occurs 25-30 days after sowing. Simplified direct seeding with $4-5 \mathrm{~g}$ seed $\mathrm{m}^{-2}$ is also reported, but with lower results in terms of plantlet emergence, with the best expectations of $30-40$ plantlets $\mathrm{m}^{-2}$.

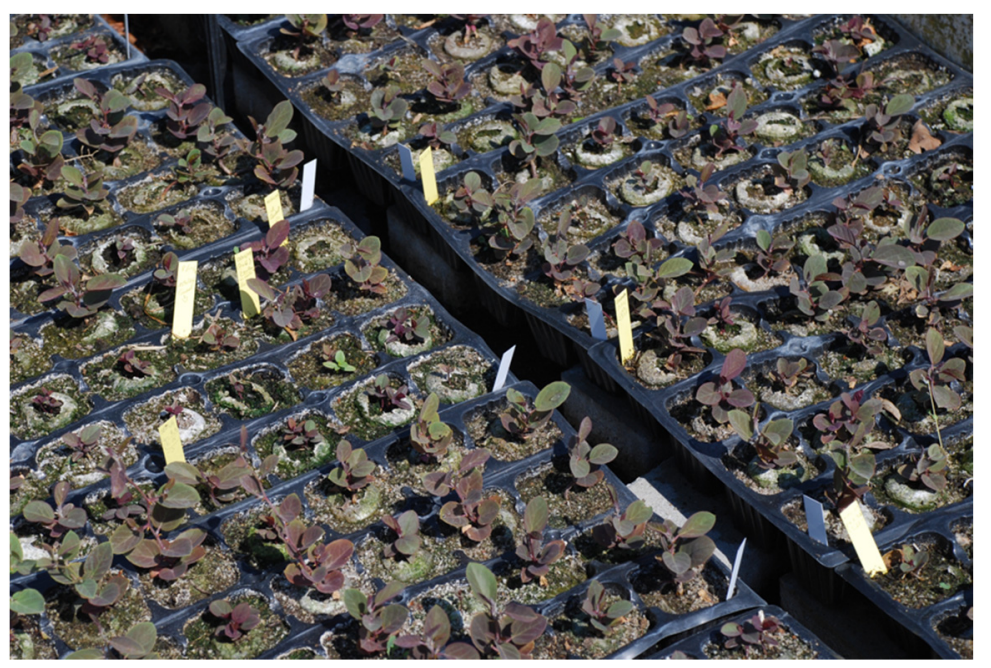

Figure 3. Experiments in seed propagation carried out in Spain at CITA by using seed of capers from Ballobar (Aragon, Spain).

Variable germination rates, considered generally low or unsatisfactory, are reported in the scientific literature $[18,36,43,47,48]$. Most of the unsuccessful results have been almost unanimously related to morphological and physiological seed characteristics such as the thick, lignified structures of the seed integuments [44] and the mucilage surrounding the seeds, developed in contact with excessive water, which represents an effective barrier against the diffusion of oxygen to the embryo [43]. However, recently it was demonstrated that this barrier can be easily removed through seed leaching for $12 \mathrm{~h} \mathrm{[49].}$

Additionally, it must be considered that the poorer germination percentages are reported mainly after direct sowing into the field [26], where disturbing factors, such as predator activity, inter alia, cannot be excluded. Several other factors can also affect the final germination percentage such as seed viability, degree of fruit ripening, fruit position on the plant and fruit weight [50]. Furthermore, the extreme heterogeneity of the results present in the scientific literature so far is an indication of the inherent genetic variability of the utilized seed lots, as affected by seed provenance but also by hybridization phenomena that are likely to occur among both the wild and cultivated forms of C. spinosa L. [5,16,17,51-53].

At the same time, an effect on germination exerted by cross-pollination between different ecotypes or accessions of $C$. spinosa cannot be excluded. However, to the best of our knowledge, no specific data on such an issue are available in the scientific literature and, therefore, it may be of interest to be studied also for breeding purposes. Different techniques can be used to improve the germination performance of woody perennials [54]. These consist of treatments to overcome embryo dormancy and/or physical-mechanical dormancy. The latter is generally removed through the effects on the seed covering by stratification (softening) or scarification (scratching). Embryo dormancy, a physiological status under hormonal control, can be overcome by seed vernalization in outdoor beds during winter or in climatic chambers and/or by the application of various chemicals and plant growth regulators (PGRs) such as gibberellins (GA), cytokinins and other substances. Most of these possible treatments, with variable results, have been tested on C. spinosa L., and have been partly reviewed by Sozzi and co-workers [36]: mechanical scarification, stratification, soaking in hot water $\left(55-85^{\circ} \mathrm{C}\right)$, concentrated $\mathrm{H}_{2} \mathrm{SO}_{4}$ or $\mathrm{H}_{2} \mathrm{O}_{2}$, or in $0.2 \%$ $\mathrm{KMnO}_{4}, 0.2 \% \mathrm{KNO}_{3}$, gibberellin $\left(\mathrm{GA}_{4+7}\right)$ or gibberellic acid $\left(\mathrm{GA}_{3}\right)$ aqueous solutions, and 
by manipulation of the environmental conditions (light/dark, temperature). A significant advantage (100\% viable embryos germinated within 3-4 days) was obtained by partially removing the seed coats from non-germinated seeds [44]; thus, the authors underlined the supposed inhibitory role exerted by seed integuments. The combined effect of ultrasonic wave treatments $(1700 \mathrm{KHz})$, applied in the presence of $\mathrm{GA}_{3}$, proved able to increase the germination percentage [55]. In an experiment carried out in vitro, high seed germination percentage was achieved on MS medium deprived of hormones $(71 \%)$ and on sterile water $(64 \%)$ after a dormancy-breaking treatment by coat scarification [56]. Cold stratification showed positive effects on germination percentage and rate [22,37].

In a study performed on the effects of soaking period and $\mathrm{GA}_{3}$ addition [57], it was concluded that adding a GA solution to the substrate, after acid scarification, was a simple and effective method to ensure satisfactory caper seed germination, although a possible negative effect of acid scarification on successive seedling growth has been reported, together with negative effects of different levels of salinity on germination [58]. In another experiment, a soaking period of 30 days or longer, with or without the addition of a $\mathrm{GA}_{3}$ solution to the substrate, proved to enhance seed germination speed, duration and percentage (up to $95-99 \%$ ) [59].

In a study aimed at the evaluation of caper seed germination, under interaction of different concentrated sulfuric acid (CSA) and $\mathrm{GA}_{3}$ concentrations, it was found that CSA for $30 \mathrm{~min}$ and 200,300 or $400 \mathrm{mg} \mathrm{L}^{-1} \mathrm{GA}_{3}$ solutions led to the highest ( $\left.60 \%\right)$ germination percentages [29], leading the authors to underline the greater opportunity to combine both scarification and $\mathrm{GA}_{3}$ treatments. Similar results ( $62 \%$ seed germination) were obtained in India using sulfuric acid ( $40 \mathrm{~min}$ ), followed by dipping in $400 \mathrm{ppm} \mathrm{GA}_{3}$ for $2 \mathrm{~h} \mathrm{[60]} \mathrm{using}$ C. spinosa seeds harvested in the wild, cold desert of the Ladakh region and in Turkey, with seeds initially immersed in warm water $\left(40^{\circ} \mathrm{C}\right)$ and then treated with $\mathrm{H}_{2} \mathrm{SO}_{4}$ for $20 \mathrm{~min}$ and $2000 \mathrm{mg} \mathrm{L}^{-1}$ of $\mathrm{GA}_{3}$ for $24 \mathrm{~h} \mathrm{[61].}$

In agreement with the above-reported results, acid scarification followed by addition of $\mathrm{GA}_{3}$ solution to the germination substrate and one week chilling was reported as a simple, efficient and cost-effective method for ensuring satisfactory seed germination in an experiment carried out in Kuwait [62], where a significant variation in germination percentage due to germination substrate was also evidenced.

The effects of different growing media and sowing depths on seed germination of caper have been more recently compared on Capparis ovata by Olmez and Olmez [63], who reported the highest germination percentage $(51.1 \%)$ with peat+perlite+manure (2:1:1) at $1.0 \mathrm{~cm}$ sowing depth. Accelerated caper seed (cv. Común) ageing for 24, 48, 72 or $96 \mathrm{~h}$ at $45^{\circ} \mathrm{C}$ was found to improve germination percentage (>90\%) compared to non-aged seeds [64]. In research carried out in Syria on the effects of gamma irradiation on the germination of caper seed cultured in vitro [65], a significant effect of irradiation at the 100 Gy dose on dormancy breaking and germination (50\%) of caper seeds was observed. In contrast, unsatisfactory germination results were observed [60] using gamma rays at different doses (10 to $50 \mathrm{KR}$ ) along with concentrated $\mathrm{H}_{2} \mathrm{SO}_{4}$ treatments for different durations. A synergistic effect of $\mathrm{GA}_{3}(250 \mathrm{ppm})$ and $\mathrm{KNO}_{3}\left(8000 \mathrm{mg} \mathrm{L}^{-1}\right.$ for $\left.24 \mathrm{~h}\right)$, useful to improve seed germination of caper (up to $72 \%$ ), was observed in an Iranian experiment with seeds placed on filter paper [66]. Satisfactory caper germination percentage and germination rate (up to $75 \%$ and 1.35, respectively) were reported in another Iranian experiment, after treatment with sulfuric acid for $15 \mathrm{~min}$, and $2000 \mathrm{ppm} \mathrm{GA}$, under alternate $20-30{ }^{\circ} \mathrm{C}$ temperatures [67]. The use of salicylic acid and GA significantly increased germination and seedling growth in C. spinosa under drought stress [68].

The influence of the genetic factor on germination performance was studied, comparing seeds of C. spinosa L., subsp. rupestris with seeds of the subspecies spinosa, where the seeds of the former subspecies germinated earlier and to a greater extent than those of the latter subspecies [46]. In a parallel experiment, the effectiveness of the germination procedures was conditioned by the time elapsed between harvesting the seeds and their seeding. In fact, seeds' germination performance decreased with increasing storage period, 
so that the highest germination percentages ( $>90 \%$ ) were obtained within 30 days from seed collection [46].

The exposure of caper seeds to magnetic fields (125-250 millitesla) had a positive effect on seed germination (82\%) when combined with the addition of GA to the substrate [69].

Lastly, Foschi and co-workers [70], comparing the germination performance of intact seeds, scrapped seeds, cracked seeds and broken seeds of different provenance, clearly demonstrated that caper seeds do not have a water-impermeable coat sensu stricto. In other words, caper seeds do not present a real physical dormancy but rather showed the presence of a physiological dormancy. In fact, with the use of $500 \mathrm{mg} \mathrm{L}^{-1} \mathrm{GA}$, they obtained that all viable seeds germinated. These observations led the authors (i) to suggest a sort of "push power" of the embryo, evoked by GA, able to reduce seed mechanical resistance to embryo expansion, thus allowing germination, and (ii) to conclude that imbibition of caper seeds is not a determining factor in their germination.

\section{Vegetative Propagation}

Vegetative propagation (syn.: multiplication, asexual or clonal propagation) is based on the capacity of shoots, leaves and roots, once detached from the mother plant, to regenerate the lacking part of the plant by emitting new roots or adventitious buds, or to join together (grafting) to form a new functional plant identical to the mother plant [71]. Therefore, compared to seed propagation, vegetative propagation of mature, selected plant material offers the main advantages, inter alia, to overcome both seedling juvenility and the undesirable heterogeneity that is found in plantations obtained by seed. Multiplication comprises self-rooting, layering, grafting and budding techniques. Among these, selfrooting is the most utilized for caper, although C. spinosa L. is commonly considered a difficult-to-root woody species, strongly dependent for the achievement of good results on plant material and seasonal and environmental parameters [72].

Different self-rooting techniques have long been tested and applied to C. spinosa and are currently adopted in Spain and in the Aeolian island of Salina. In these areas, despite the erratic response of rooting generally reported [18,37], caper is often propagated by stem cuttings. This is the standard method for 'Mallorquina' and 'Italiana' in Spain, and 'Nocella' and 'Spinoso' in Salina [16,26], even if plants obtained by cuttings are reputed by the farmers to be more susceptible to drought, at least in the first years of plantation [16]. Regarding the different types of cuttings, the worst results have been obtained in Spain and in Italy (Figure 4) with semi-hardwood cuttings collected and planted during August and September. Conversely, appreciable results have been obtained with hardwood and softwood cutting utilization. Woody cuttings, 12 to $30 \mathrm{~cm}$ long and 1.0 to $2.5 \mathrm{~cm}$ in diameter, are taken in autumn at the base of the mother plant, from 1-year-old wood. They are then stored in cold and humid conditions (sand stratification or cold room at 3-4 ${ }^{\circ} \mathrm{C}$ ), after a fungicide treatment, until their planting (February) in the nursery section, covered by shading nets, with or without the application of indolebutyric acid (IBA) or naphthaleneacetic acid (NAA). Sometimes, two to three short longitudinal incisions are made at the base of the cuttings, and the use of bottom-heated systems is strongly recommended. Unfavorable results have been obtained with the 'Del País' variety, which may be considered recalcitrant. With the use of bottom-heated systems, 95\% to 100\% rooting for hardwood cuttings of 'Mallorquina' has been reported [37]. Softwood cuttings, 6 to $9 \mathrm{~cm}$ long, and $>3 \mathrm{~mm}$ in diameter, are taken in spring (April) and are exclusively rooted in the nursery where the use of bottom-heated systems and intermittent mist propagation techniques are recommended [37]. 


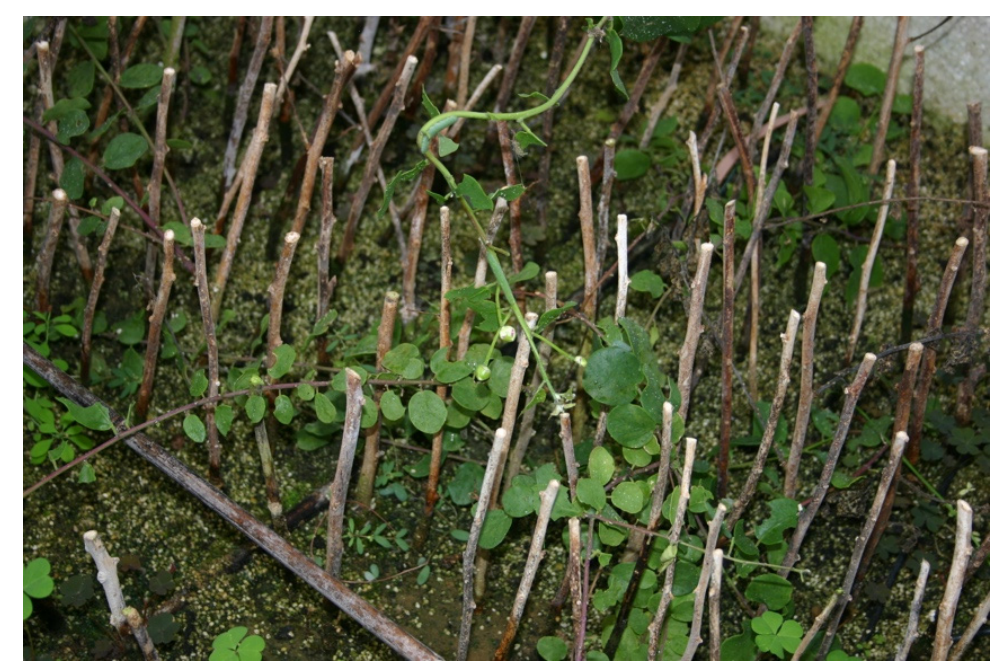

Figure 4. Vegetative propagation by rooting during experiments at the University of Palermo, Italy.

Variation in the rooting potential of caper cuttings has been generally reported as affected by the type of cutting, cutting harvest time and by the PGR and substrate utilized $[73,74]$. In Italy, dipping the basal end of the cutting into $1500-3000 \mathrm{mg} \mathrm{L}^{-1}$ IBA solution enhanced rooting, depending on the type of cutting and the season in which cuttings were taken, with rooting percentages under mist propagation or heated bed systems between $55 \%$ and $75 \%$ with hardwood cuttings taken in March-April, corresponding to the initial bud-break phase [75,76]. On the other hand, herbaceous (softwood) cuttings, taken at the beginning of the vegetative cycle (April), showed more satisfactory results, with $90 \%$ rooting success, in the case of spineless caper biotypes rather than with spiny ones [77]. Cutting diameter has been generally reported to be determinant for the result in various studies $[16,37,78]$ and, ordinarily, the best results have been achieved with values at least 5-6 $\mathrm{mm}$ or even higher, and not below $3 \mathrm{~mm}$, for hardwood and softwood cutting, respectively. A positive correlation between cutting diameter and rhizogenesis success has been reported for hardwood and semi-hardwood cuttings, as well as a positive effect of sealing the top- and the bottom-end of cuttings with paraffin [46].

Besides depending on the type of cuttings, rhizogenesis results have varied depending on the presence of leaves (leafy or leafless cuttings). Leafy cuttings treated with 6000 and $9000 \mathrm{mg} \mathrm{L}^{-1}$ IBA showed higher rhizogenesis percentages (67\%) than leafless ones (61\%) [29]. Additionally, in the same research, IBA positively affected root number per cutting more than NAA, but both PGRs did not differ in terms of cuttings' root length, which was significantly higher than in the controls.

The use of irradiation with low doses of gamma radiation (10 Gy) stimulated (in vitro) rooting of shoots from $75 \%$ to $100 \%$ [65].

Grafting, as a propagation technique, is the least used method in capers. In Spain, satisfactory results $(60 \%$ scion take) were obtained using bark grafting in mature plantings. Nurseries generally whip-graft with survival rates of $73 \%$ [37]. Both systems are now considered excessively expensive and are, therefore, no longer practiced.

\section{In Vitro Propagation}

The advancement of scientific knowledge and the development of practical techniques have permitted, in recent decades, the constant progress of in vitro plant biotechnologies, particularly those useful to multiply hard-to-propagate woody species by conventional methods [79]. In vitro growth and development are promoted by PGRs which are responsible for cell division and growth. PGRs (auxin and cytokinin) regulate the development of different plant organs during in vitro growth. The auxins (IAA, IBA, NAA or 2,4dichlorophenoxyacetic acid (2,4-D)) induce cell elongation and tissue swelling, cell division (callus proliferation) and the formation of adventitious roots; the cytokinins (kinetin, ben- 
zylaminopurine (BAP), meta-topolin (mT), 2-isopentenyladenine (2iP) or zeatin (ZEA)) stimulate growth and development. They also improve cellular division and induce the formation of adventitious shoots by decreasing the apical dominance.

Even in the case of $C$. spinosa L., micropropagation has recently offered an interesting and promising alternative for rapidly obtaining, starting from a single explant, highly uniform, pathogen-free plant material, suitable both for specialized plantings and ex situ conservation (Figure 5).
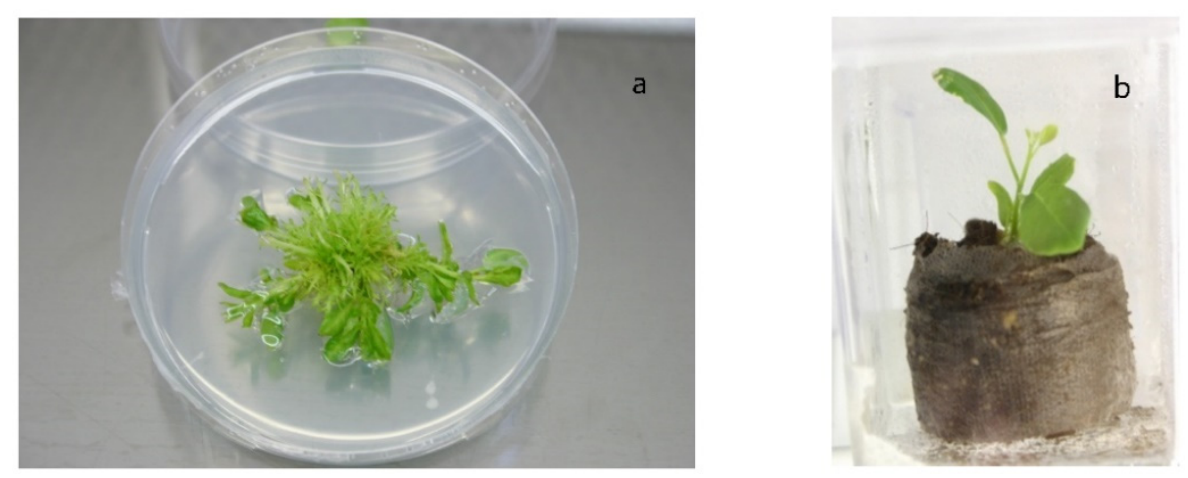

Figure 5. In vitro propagation carried out at the University of Palermo. Experiments on proliferation (a) and on the initial phase of ex vitro acclimatization (b).

In vitro C. spinosa L. propagation was reported for the first time in 1984 [80] and soon after, it was followed by other studies which mainly dealt with nodal segments as starting material $[56,65,80-83]$. Others have reported successful micropropagation protocols regarding other caper-related diverse species, beyond the scope of the present review, such as, for example, C. decidua (Forsk.) Edgew [84,85], or C. orientalis Duh. and C. leucophylla DC. [86,87].

Limiting our analysis to C. spinosa L., it was evident that in most of these studies the best results, in terms of the induction of axillary growth, were obtained with cytokinins (mainly BAP) and auxins, used either alone or in combination. Due to C. spinosa's reputation as a hard-to-root species, the in vitro rooting phase is considered critical for caper propagation. High rooting responses $(70 \%)$ of local caper populations of unreported origin were obtained in 1990 [80] using IAA at $5.25 \mathrm{mg} \mathrm{L}^{-1}$, even though there were marked differences among different tested auxins and concentrations in terms of rooting efficacy. Subsequently, other authors have reported high success rates (80-100\%) for the rooting phase. In Lebanon, the rooting percentage of a local ecotype was improved up to $80.5 \%$ with IBA at $5 \mathrm{mg} \mathrm{L}^{-1}$ for $10 \mathrm{~min}$ [81] and in another experiment on explants from a Lebaneseselected mature shrub, a high rooting response (87-92\%) of shoots was obtained after a $4 \mathrm{~h}$ pulse treatment with IAA at $100 \mathrm{mg} \mathrm{L}^{-1}$ [88]. In Tunisia, on explants coming from one-year-old mother plants of a local ecotype, the maximum rooting $(80 \%)$ was obtained with IAA at $1.5 \mathrm{mg} \mathrm{L}^{-1}$ [77]. On plant material proceeding from Sicily, rooting percentages up to $87 \%$ with IBA at $100-200 \mathrm{mg} \mathrm{L}^{-1}$ were reported [89]. In Jordan, the best auxin for in vitro rooting $(80 \%)$ of wild caper plants material was IAA at the level of $5.0 \mathrm{mg} \mathrm{L}^{-1}$ [82]. In Syria, the effect of gamma irradiation on the growth of wild caper explants was studied. A 10 Gy dose of gamma irradiation stimulated in vitro growth of shoots up to $200 \%$ [65].

In a study on plant material proceeding from Jordan, maximum root formation percentage $(60 \%)$ was obtained with $2.0 \mathrm{mg} \mathrm{L}^{-1}$ IAA, but similar successful results with IBA and NAA at various concentrations were also reported [90]. On plant material obtained from a mature plant of a Sicilian selected genotype (code ICAORL2), grown in the collection of the University of Palermo, a high percentage (93.7\%) of well-rooted plantlets was achieved with the synthetic phenylurea $\mathrm{N}, \mathrm{N}^{\prime}$-bis-(2,3-methylenedioxyphenyl)urea (2,3-MDPU) $(1 \mu \mathrm{M})$ [78]. In a study carried out in Saudi Arabia, aimed at exploring in vitro culture protocols for ex situ conservation purposes, using axillary buds of wild C. spinosa L. 
plants, the highest percentage of rooted shoots (56.7\%) was observed on half-strength MS medium without NAA and on full MS with $1.5 \mathrm{mg} \mathrm{L}^{-1}$ NAA [91].

A new technique to regenerate caper plants starting from floral explants (unfertilized ovules) on MS medium, supplemented with $88 \mathrm{mM}$ sucrose and $13 \mu \mathrm{M}$ BAP, was successfully developed by Carra and co-workers [92]. Multiple shoots were obtained on MS medium supplemented with BAP and IBA. The best rooting results (100\% of rooted explants) were obtained when explants were dipped for $10 \mathrm{~min}$ in $50 \mu \mathrm{M}$ IBA solution and successively maintained in PGR-free medium. In another experiment carried out on selected Sicilian genotypes, IBA showed better rooting performances than IAA and NAA at all the tested concentrations $(1,5,10 \mu \mathrm{M})$. The best rooting rate $(93.4 \%)$ was achieved with IBA at $5 \mu \mathrm{M}$ [93].

The usefulness of PlantForm bioreactors as an alternative to traditional solid-substrate techniques was tested on plant material obtained from mature plants of three Sicilian selected accessions, named 'Sal 39', 'Sal 37' and 'Sal 35', grown on the Aeolian island of Salina [94]. The results show that the caper shoots from bioreactors demonstrated good adaptability and better growth rates. Furthermore, the relative growth and real proliferation rate of the caper explants were higher when using $\mathrm{mT}$ (eight new proliferated shoots after 60 days) than when using BAP as a PGR (five new proliferated shoots after 60 days).

In a successive experiment, carried out on plant material from the three same aforementioned accessions, low rooting efficiency with IBA and no response to rooting with IAA was found at the tested concentrations. The maximum rooting performances were observed for only one of the tested accessions ('Sal 39') when explants, proceeding from liquid culture in PlantForm, were supplemented with NAA at $0.75 \mathrm{mg} \mathrm{L}^{-1}+$ IBA at $0.25 \mathrm{mg} \mathrm{L}^{-1}$, indicating the importance of the role exerted by the cultural conditions during the proliferation phase. Additionally, these results confirm that mixtures of root-promoting substances are sometimes more effective than either component alone.

Finally, it must be observed that rooting induction often required high levels of auxins which, on the other hand, may stimulate callus formation [88,93]. In these conditions, the abundant presence of callus delays root formation [90] and is unfavorable for ex vitro transfer. Moreover, high concentrations of auxins could be inhibitory for root growth [94] and may be the cause of somaclonal variation in the production cycle [95].

Altogether these results clearly confirm, as has already been pointed out [85], that for an individual genotype, or even the same local population, the rate of rooting is strongly determined by the type and concentration of auxin, but, considered as a whole, they also seem to indicate that no one protocol, although optimal with a specific accession, may fit all genotypes $[94,96]$.

\section{Conclusions}

The caper (C. spinosa L.) has long been considered a difficult-to-propagate species. In this review, a comparative analysis carried out on the most significant scientific contributions to the issue of both conventional and innovative propagation has led us to prudently confirm this reputation only in part. In fact, far from being able to consider all the specific problems related to the different propagation technologies to be overcome, it has nevertheless clearly emerged that, given the right conditions and the appropriate protocols applied to specific accessions, more than satisfactory results are possible with most of the conventional and innovative available technologies. Furthermore, it is probable that erratic or unsatisfactory propagation results, variously reported, must be linked to the extreme heterogeneity of the plant materials used, rather than to intrinsic limits of the adopted technologies. In this context of the high variability existing within the taxon, we can still consider C. spinosa $\mathrm{L}$. as a difficult-to-propagate species, sensu lato.

However, from an agronomic point of view, the unreliability and low degree of transferability of propagation research results are strongly indicative that the caper industry, including related nursery systems, is still in its infancy. This is also supported by the evidence of the extreme, unjustified emphasis that has been reserved so far for sexual 
reproduction, as emerged from the present review. In woody perennial fruit plants, seed propagation is usually reserved only for rootstocks and genetic improvement, whereas vegetative (clonal) propagation is the most frequent and appropriate method for specialized woody crops to assure specific phenotypes of agronomic and commercial interest. Caper, as a crop, has a recent history and can be considered only a semi-domesticated or a predomesticated crop, due to the substantial absence of breeding and "crop improvement" within the cultivated accessions, i.e., the absence of real "cultivars". Even if the caper is the subject of intense trade between producing countries and importing countries (mainly the USA and the UK) it can also be, therefore, included among the "orphan crops", since it has certainly received, so far, less attention in terms of research, mainly with respect to the selection of well-adapted, valuable and easy-to-propagate candidate cultivars. For the improvement and modernization of the caper culture it is, therefore, essential that research concentrates efforts on genetic improvement programs, starting from the valorization of the vast genetic potential existing within the germplasm, both in nature and under cultivation.

The ideotype should include high productivity of a large number of deep green, rounded, easy-to-pick flower buds; tender shoots needing heavy pruning with rapid regrowth; soft, light green, oval-shaped caper berries with few seeds; short internodes; good resistance to pests and diseases; spineless or with a scarce number of spines; and, ultimately, easy vegetative propagation.

Unfortunately, the drastic decline suffered by the caper industry-which decreased in Spain, for instance, from over 7500 hectares in 1984 to 550 in 2008 and to 483 hectares in 2018-suggests an equally drastic drop in interest in research investments for caper in the near future. On the other hand, imports from North Africa, and other countries where labor is cheaper, but where caper is mainly harvested in the wild, will most likely increase the risk of genetic erosion to unsustainable levels. To try to counter this trend, the improvement of current conventional and innovative propagation techniques can play an essential role both in the conservation of genetic resources and in varietal crop cross-breeding. At the same time, decisive is the inversion of the tendency to cultivation abandonment, potentially driven by a renewed agronomic research interest.

However, on the basis of the state of the art discussed in the present review, it is conclusively possible to assert that the caper, as a crop, must no longer be reputed as a difficult-to-propagate crop sensu stricto, given the most modern and appropriate technologies available and, above all, once a range of proven reliable cultivars are made available.

Author Contributions: Conceptualization, F.S., C.P. and E.B.; methodology, F.S., M.B.D.S. and E.B.; resources, C.C., M.B.D.S.; data curation, F.S., M.B.D.S. and C.C.; writing-original draft preparation, F.S. and C.C.; writing-review and editing, F.S., C.P. and E.B. All authors have read and agreed to the published version of the manuscript.

Funding: This research received no external funding.

Institutional Review Board Statement: Not applicable.

Informed Consent Statement: Not applicable.

Conflicts of Interest: The authors declare no conflict of interest.

\section{References}

1. Fici, S. Intraspecific variation and evolutionary trends in Capparis spinosa L. (Capparaceae). Plant Syst. Evol. 2001, 228, 123-141. [CrossRef]

2. Ciftcioglu, G.C.; Ebedi, S.; Abak, K. Evaluation of the relationship between ornamental plants-based ecosystem services and human wellbeing: A case study from Lefke Region of North Cyprus. Ecol. Indic. 2019, 102, 278-288. [CrossRef]

3. Gianguzzi, L.; Bazan, G. A phytosociological analysis of the Olea europaea L. var. sylvestris (Mill.) Lehr. forests in Sicily. Plant Biosyst.-Int. J. Deal. Asp. Plant Biol. 2020, 154, 705-725. [CrossRef]

4. Distefano, G.; Caruso, M.; La Malfa, S.; Ferrante, T.; Del Signore, B.; Gentile, A.; Sottile, F. Genetic diversity and relationships among Italian and foreign almond germplasm as revealed by microsatellite markers. Sci. Hortic. 2013, 162, 305-312. [CrossRef]

5. Fici, S. A taxonomic revision of the Capparis spinosa group (Capparaceae) from eastern Africa to Oceania. Phytotaxa 2015, 203, 24. [CrossRef] 
6. $\quad$ Rivera, D.; Inocencio, C.; Obon, C.; Carreno, E.; Reales, A.; Alcaraz, F. Archaeobotany of capers (Capparis) (Cappa-raceae). Veg. Hist. Archaeobot. 2002, 11, 295-313. [CrossRef]

7. Bounous, G.; Barone, E. Prospettive di sviluppo di specie legnose per le zone aride e semi-aride del Meridione e nuovi criteri di utilizzo: Capero. Terra Sole 1989, 568, 733-735.

8. Rivera, D.; Inocencio, C.; Obon, C.; Alcaraz, F. Review of Food and Medicinal Uses of Capparis L. Subgenus Capparis (Capparidaceae). Econ. Bot. 2003, 57, 515-534. [CrossRef]

9. Gull, T.; Anwar, F.; Sultana, B.; Alcayde, M.A.C.; Nouman, W. Capparis species: A potential source of bioactives and high-value components: A review. Ind. Crops Prod. 2015, 67, 81-96. [CrossRef]

10. Anwar, F.; Anwar, F.; Muhammad, G.; Ajaz Hussain, M.; Zengin, G.; Alkharfy, K.M.; Alkharfy, K.M.; Ashraf, M.; Gilani, A.H.; Gilani, A.H. Capparis spinosa L.: A plant with high potential for development of functional foods and nutraceuticals/pharmaceuticals. Int. J. Pharmacol. 2016, 12, 201-219. [CrossRef]

11. Maldini, M.; Foddai, M.; Natella, F.; Addis, R.; Chessa, M.; Petretto, G.L.; Tuberoso, C.I.G.; Pintore, G. Metabolomic study of wild and cultivated caper (Capparis spinosa L.) from different areas of Sardinia and their comparative evaluation. J. Mass Spectrom. 2016, 51, 716-728. [CrossRef] [PubMed]

12. Zhang, H.; Ma, Z.F. Phytochemical and Pharmacological Properties of Capparis spinosa as a Medicinal Plant. Nutritions 2018, 10, 116. [CrossRef]

13. Grimalt, M.; Hernández, F.; Legua, P.; Almansa, M.S.; Amorós, A. Physicochemical composition and antioxidant activ-ity of three Spanish caper (Capparis spinosa L.) fruit cultivars in three stages of development. Sci. Hortic. 2018, 240, 509-515. [CrossRef]

14. Lo Bosco, F.; Guarrasi, V.; Moschetti, M.; Germanà, M.A.; Butera, D.; Corana, F.; Papetti, A. Nutraceutical Value of Pan-telleria Capers (Capparis spinosa L.). J. Food Sci. 2019, 84, 2337-2346. [CrossRef]

15. Mollica, A.; Stefanucci, A.; Macedonio, G.; Locatelli, M.; Luisi, G.; Novellino, E.; Zengin, G. Chemical composition and biological activity of Capparis spinosa L. from Lipari Island. S. Afr. J. Bot. 2019, 120, 135-140. [CrossRef]

16. Barbera, G.; Di Lorenzo, R.; Barone, E. Observations on Capparis populations cultivated in Sicily and on their vegetative and productive behaviour. Agric. Mediterr. 1991, 121, 32-39.

17. Gristina, A.S.; Fici, S.; Siragusa, M.; Fontana, I.; Garfi, G.; Carimi, F. Hybridization in Capparis spinosa L.: Molecular and morphological evidence from a Mediterranean island complex. Flora-Morphol. Distrib. Funct. Ecol. Plants 2014, $209,733-741$. [CrossRef]

18. Barbera, G.; Di Lorenzo, R. The Caper Culture in Italy. Acta Hortic. 1984, 144, 167-172. [CrossRef]

19. Gruère, G.P.; Giuliani, A.; Smale, M. Marketing underutilized plant species for the poor: A conceptual framework. In Agrobiodiversity Conservation and Economic Development; Routledge: London, UK, 2008; pp. 62-81.

20. Renna, M.; Montesano, F.F.; Serio, F.; Gonnella, M. The Mediterranean Diet between Traditional Foods and Human Health through Culinary Examples; Elsevier BV: Amsterdam, The Netherlands, 2021; pp. 75-99.

21. Chedraoui, S.; Abi-Rizk, A.; El-Beyrouthy, M.; Chalak, L.; Ouaini, N.; Rajjou, L. Capparis spinosa L. in A systematic re-view: A xerophilous species of multi values and promising potentialities for agrosystems under the threat of global warming. Front. Plant Sci. 2017, 8, 1-18. [CrossRef]

22. Olmez, Z.; Gokturk, A.; Gulcu, S. Effects of cold stratification on germination rate and percentage of caper (Capparis ovata Desf.) seeds. J. Environ. Biol. 2006, 27, 667-670. [PubMed]

23. Gan, L.; Zhang, C.; Yin, Y.; Lin, Z.; Huang, Y.; Xiang, J.; Fu, C.; Li, M. Anatomical adaptations of the xerophilous me-dicinal plant, Capparis spinosa, to drought conditions. Hortic. Environ. Biotechnol. 2013, 54, 156-161. [CrossRef]

24. Levizou, E.; Drilias, P.; Kyparissis, A. Exceptional Photosynthetic Performance of Capparis spinosa L. Under Adverse Conditions of Mediterranean summer. Photosynthetica 2004, 42, 229-235. [CrossRef]

25. Pugnaire, F.I.; Esteban, E. Nutritional adaptations of caper shrub (Capparis Ovata Desf.) to environmental stress. J. Plant Nutr. 1991, 14, 151-161. [CrossRef]

26. Sozzi, G.O. Caper bush: Botany and Horticulture. In Horticultural Reviews; Janick, J., Ed.; John Wiley \& Sons.: Hoboken, NJ, USA, 2001; Volume 27, pp. 125-188. ISBN 9780471387909.

27. Puche, J.L. Ministerio de Agricultura, 1977th ed.; Hojas Divulgadoras del Ministerio de Agricultura: Madrid, Spain, 1977; ISBN 84-341-0143-2.

28. Rhizopoulou, S.; Psaras, G.K. Development and structure of drought-tolerant leaves of the Mediterranean shrub Capparis spinosa L. Ann. Bot. 2003, 92, 377-383. [CrossRef] [PubMed]

29. Ramezani-Gask, M.; Bahrani, M.; Shekafandeh, A. A comparison of different propagation methods of common Caper-bush (Capparis spinosa L.) as a new horticultural crop. Int. J. Plant Dev. 2008, 2, 106-110.

30. Sakcali, M.S.; Bahadir, H.; Ozturk, M. Eco-physiology of capparis spinosa L: A plant suitable for combating desertification. Pak. J. Bot. 2008, 40, 1481-1486.

31. Neyisci, T. A study on the slow burning plant species suitable for controlling forest fires' (summary in English). Turk. J. Agric. For. 1987, 11, 595-604.

32. Ashraf, U.; Chaudhry, M.N.; Ahmad, S.R.; Ashraf, I.; Arslan, M.; Noor, H.; Jabbar, M. Impacts of climate change on Capparis spinosa L. based on ecological niche modeling. PeerJ 2018, 6, e5792. [CrossRef] 
33. Rankou, H.; M'Sou, S.; Diarra, A.; Ait Babahmad, R.A. Capparis Spinosa. The IUCN Red List of Threatened Species 2020: E.T137745831A139593491. 2020. Available online: https://www.iucnredlist.org/species/137745831/139593491 (accessed on 17 July 2021).

34. Padulosi, S. Priority-setting for underutilized and neglected plant species of the Mediterranean region. In Proceedings of the Report of the IPGRI Conference, Aleppo, Syria, 9-11 February 1998; Padulosi, S., Ed.; IPGRI: Rome, Italy, 1999.

35. Padulosi, S.; Hodgkin, T.; Williams, J.T.; Haq, N. Underutilized crops: Trends, challenges and opportunities in the 21st century. In Managing Plant Genetic Diversity, Proceedings of the International Conference, Kuala Lumpur, Malaysia, 12-16 June 2000; CABI: Wallingford, UK, 2002; pp. 323-338.

36. Sozzi, G.; Peter, K.V.; Babu, K.N.; Divakaran, M. Capers and caperberries. In Handbook of Herbs and Spices; Elsevier: Amsterdam, The Netherlands, 2012; Volume 2, pp. 193-224.

37. Luna Lorente, F.; Perez Vicente, M. La Tapenera o Alcaparra. Cultivo y Aprovechamiento; Publicaciones de Extension Agraria: Madrid, Spain, 1985; ISBN 84-341-0382-6.

38. Barbera, G. Le caprier (Capparis spp.); EUR 13617; Commission des Communautés Européennes: Luxembourg, 1991; ISBN 9282629783.

39. Fici, S.; Lo Valvo, F. Seed dispersal of Capparis spinosa L. (Capparaceae) by Mediterranean lizards. Nat. Sicil. 2004, 28, 1147-1154.

40. La Mantia, T.; Rühl, J.; Massa, B.; Pipitone, S.; Lo Verde, G.; Bueno, R.S. Vertebrate-mediated seed rain and artificial perches contribute to overcome seed dispersal limitation in a Mediterranean old field. Restor. Ecol. 2019, 27, 1393-1400. [CrossRef]

41. Vigni, I.L.; Melati, M.R. Examples of seed dispersal by entomochory. Acta Bot. Gallica 1999, 146, 145-156. [CrossRef]

42. Yang, Y.; Lin, Y.; Shi, L. The effect of lizards on the dispersal and germination of Capparis spinosa (Capparaceae). PLoS ONE 2021, 16, e0247585. [CrossRef]

43. Orphanos, P.I. Germination of caper (Capparis spinosa L.) seeds. J. Hortic. Sci. 1983, 58, 267-270. [CrossRef]

44. Sozzi, G.O.; Chiesa, A. Improvement of caper (Capparis spinosa L.) seed germination by breaking seed coat-induced dormancy. Sci. Hortic. 1995, 62, 255-261. [CrossRef]

45. Pascual, B.; San Bautista, A.; López-Galarza, S.; Alagarda, J.; Maroto, J.V. Germination behaviour after storage of caper seeds. Seed Sci. Technol. 2006, 34, 151-159. [CrossRef]

46. Ferrer, M.J. Estudio Para la Mejora de las Técnicas de Propagación de la Alcaparra (Capparis spinosa L.); Universitat Politecnica de Valencia: Valencia, Spain, 2018.

47. Macchia, M.; Casano, S. La propagazione del capero (Capparis spinosa L). Sementi Elette 1993, $39,37$.

48. Germanà, M.; Chiancone, B. In Vitro Germination and Seedling Development of Caper (Capparis spinosa L.) Mature Seeds. Acta Hortic. 2009, 839, 181-186. [CrossRef]

49. Tafti, M.M.; Farhoudi, M.; Rastifar, M.; Asilan, K.S. Methods of breaking seed dormancy in Caper (Capparis spinosa L.) (English summary). Iran. J. Range Desert Res. 2012, 18, 569-577.

50. Pascual, B.; San Bautista, A.; Ferreros, N.; López-Galarza, S.; Maroto, J.V. Analysis of germination of caper seeds as in-fluenced by the position of fruit on the mother plant, fruit maturation stage and fruit weight. J. Hortic. Sci. Biotechnol. 2003, 78, 73-78.

51. Zohary, M. The species of Capparis in the Mediterranean and the Near Eastern Countries. Bull. Res. Counc. Isr. 1960, 8D, 49-64.

52. Fici, S.; Gianguzzi, L. Diversity and conservation in wild and cultivated Capparis in Sicily. Bocconea 1997, 7, 437-443.

53. Inocencio, C.; Rivera, D.; Concepción Obón, M.; Alcaraz, F.; Barreña, J.-A. A Systematic Revision of Capparis Section Capparis (Capparaceae) 1, 2. Ann. Missouri Bot. Gard. 2006, 93, 122-149. [CrossRef]

54. Hartmann, H.T.; Kester, D.E.; Davies, F.T.; Geneve, R.L. Plant Propagation Principles and Practices, 7th ed.; Prentice Hall: Upper Saddle River, NJ, USA, 2002.

55. Rinaldelli, E. Effect of ultrasonic waves on seed germination of Capparis spinora L. as related to exposure time, temperature, and gibberellic acid. Adv. Hortic. Sci. 2000, 14, 182-188.

56. Chalak, L.; Elbitar, A.; Cordahi, N.; Hage, C.; Chehade, A. In Vitro Propagation of Capparis spinosa L. Acta Hortic. 2003, 616, 335-338. [CrossRef]

57. Pascual, B.; Bautista, A.S.; Imbernon, A.; López-Galarza, S.; Alagarda, J.; Maroto, J. Seed treatments for improved germination of caper (Capparis spinosa). Seed Sci. Technol. 2004, 32, 637-642. [CrossRef]

58. Bahrani, M.; Gask, M.R.; Shekafandeh, A.; Taghvaei, M. Seed germination of wild caper (Capparis spinosa L., var. parviflora) as affected by dormancy breaking treatments and salinity levels. Seed Sci. Technol. 2008, 36, 776-780. [CrossRef]

59. Pascual, B.; San Bautista, A.; Pascual Seva, N.; García Molina, R.; López-Galarza, S.; Maroto, J.V. Effects of soaking period and gibberellic acid addition on caper seed germination. Seed Sci. Technol. 2009, 37, 33-41. [CrossRef]

60. Bhoyar, M.S.; Mishra, G.P.; Singh, R.; Singh, S.B. Effects of various dormancy breaking treatments on the germination of wild caper (Capparis spinosa) seeds from the cold arid desert of trans-Himalayas. Indian J. Agric. Sci. 2010, 80, 621-625.

61. Soyler, D.; Khawar, K.M. Seed Germination of Caper (Capparis ovata var. Herbacea) Using $\alpha$ Naphthalene Acetic Acid and Gibberellic Acid. Int. J. Agric. Biol. 2007, 9, 35-37.

62. Suleiman, M.K.; Bhat, N.R.; Abdal, M.S.; Jacob, S.; Thomas, R.R.; Al-Dossery, S.; Bellen, R. Germination studies of Capparis spinosa L. Propag. Ornam. Plants 2009, 9, 35-38.

63. Olmez, Z.; Olmez, S.A. Effects of Different Growing Media and Sowing Depths on Seed Germination of Caper (Capparis Ovata Desf.). Int. J. Ecosyst. Ecol. Sci. 2017, 7, 331-336. 
64. Pascual-Seva, N.; San Bautista, A.; López-Galarza, S.; Maroto, J.V.; Pascual, B. Effect of accelerated ageing on germination in caper (Capparis spinosa L.) seeds. Acta Hortic. 2011, 898, 69-74. [CrossRef]

65. Al-Safadi, B.; Elias, R. Improvement of caper (Capparis spinosa L.) propagation using in vitro culture and gamma irradiation. Sci. Hortic. 2011, 127, 290-297. [CrossRef]

66. Arefi, I.H.; Nejad, S.K.; Kafi, M. Roles of duration and concentration of priming agents on dormancy breaking and germination of caper (Capparis spinosa L.) for the protection of arid degraded areas. Pak. J. Bot. 2012, 44, 225-230.

67. Labbafi, M.; Mehrafarin, A.; Badi, H.; Ghorbani, M.; Tavakoli, M. Improve germination of caper (Capparis spinosa L.) seeds by different induction treatments of seed dormancy breaking. Trakia J. Sci. 2018, 16, 70-74. [CrossRef]

68. Heydariyan, M.; Basirani, N.; Sharifi-Rad, M.; Khmmari, I.; Rafat Poor, S. Effect of Seed Priming on Germination and Seedling Growth of the Caper (Capparis Spinosa) Under Drought Stress. Int. J. Adv. Biol. Biomed. Res. 2014, 2, 2381-2389.

69. Juan, M.; Pascual-Seva, N.; Iranzo, D.; Pascual, B. Improvement of seed germination of caper (Capparis spinosa L.) through magnetic fields. Acta Hortic. 2020, 1273, 433-440. [CrossRef]

70. Foschi, M.L.; Juan, M.; Pascual, B.; Pascual-Seva, N. Water Uptake and Germination of Caper (Capparis spinosa L.) Seeds. Agronomy 2020, 10, 838. [CrossRef]

71. Loreti, F.; Morini, S.; Fiorino, P. Propagation. In Principles of Modern Fruit Science; Sansavini, S., Ed.; ISHS: Leuven, Belgium, 2019; pp. 191-219. ISBN 978-94-6261-204-4.

72. Sozzi, G.O.; Vicente, A.R. Capers and caperberries. In Handbook of Herbs and Spices; Peter, K.V., Ed.; CRC Press, Inc.: Washington, DC, USA, 2006; Volume 3, pp. 1689-1699. ISBN 978-0-8493-9155-2.

73. San Bautista, A.; Pascual, B.; Sospedra, S.; Lopez-Galarza, S.; Laza, P.; Maroto, J.V. Influencia de la fecha y de la sección de las ramas en el enraizamiento y la brotación de las yemas en estaquillas de alcaparra. Actas Hortic. 2006, 46, 41-45.

74. Pascual, B.; San Bautista, A.; Pascual-Seva, N.; Garcia-Molina, R.; Lopez Galarza, S.; Maroto, J.V. Estudio del enrai-zamiento de estaquillas de madera suave en alcaparra (Capparis spinosa L.). Actas Hortic. 2008, 50, 89-93.

75. Pilone, N. Variazione del potenziale rizogeno naturale nel capero. L'Inform. Agrar. 1990, 13, 69-70.

76. Pilone, N. Effetti dell'IBA sulla radicazione delle talee di Capparis spinosa in cassone riscaldato. L'Inform. Agrar. 1990, 40, 81-82.

77. Salem, A.B.; Zemni, H.; Ghorbel, A. Propagation caper (Capparis spinosa L.) by herbaceous cuttings and in vitro culture. Agric. Mediterr. 2001, 131, 42-48.

78. Abel, J.I. Estudio Para la Mejora de la Propagación de la Alcaparra Mediante Estaquillas. Ph.D. Thesis, Universitat Politècnica de València, València, Spain, 2015.

79. George, E.F.; Hall, M.A.; De Klerk, G.J. Plant Propagation by Tissue Culture, 3rd ed.; Springer: Berlin/Heidelberg, Germany, 2008; Volume 1, ISBN 9781402050053.

80. Rodriguez, R.; Rey, M.; Cuozzo, L.; Ancora, G. In vitro propagation of caper (Capparis spinosa L.). Vitr. Cell. Dev. Biol.-Anim. 1990, 26, 531-536. [CrossRef]

81. Caglar, G.; Caglar, S.; Ergin, O.; Yarim, M. The influence of growth regulators on shoot proliferation and rooting of in vitro propagated caper. J. Environ. Biol. 2005, 26, 479-485. [PubMed]

82. Musallam, I.; Duwayri, M.; Shibli, R.A. Micropropagation of Caper (Capparis spinosa L.) from Wild Plants. Funct. Plant Sci. Biotechnol. 2011, 5, 17-21.

83. Deora, N.S.; Shekhawat, N.S. Micropropagation of Capparis decidua (Forsk.) Edgew-A tree of arid horticulture. Plant Cell Rep. 1995, 15, 278-281. [CrossRef]

84. Tyagi, P.; Kothari, S.L. Micropropagation of Capparis decidua through In Vitro Shoot Proliferation on Nodal Explants of Mature Tree and Seedling Explants. J. Plant Biochem. Biotechnol. 1997, 6, 19-23. [CrossRef]

85. Carra, A.; Del Signore, M.B.; Sottile, F.; Ricci, A.; Carimi, F. Potential use of new diphenylurea derivatives in micro-propagation of Capparis spinosa L. Plant Growth Regul. 2012, 66, 229-237. [CrossRef]

86. Hegazi, G.A.; Eid, S.R.; El, A.; Sharaf, M.M. Micropropagation for conservation of two rare Capparis species from Egypt 1. Catrina 2011, 6, 29-39.

87. Kereša, S.; Stanković, D.; Lodeta, K.B.; Jerčić, I.H.; Bolarić, S.; Barić, M.; Mihovilović, A.B. Efficient Protocol for the In Vitro Plantlet Production of Caper (Capparis orientalis Veill.) from the East Adriatic Coast. Agronomy 2019, 9, 303. [CrossRef]

88. Chalak, L.; Elbitar, A. Micropropagation of Capparis spinosa L. subsp. Rupestris Sibth. \& Sm. by nodal cuttings. Indian J. Biotechnol. 2006, 5, 555-558.

89. Tian, X.-X.; Jiang, C.-Q.; Chen, X.-Y.; Qu, S.; Yang, W.-S. Studies on the tissue culture of axillary bud and rapid propa-gation in the Capparis spinosa (Abstract). For. Res. 2009, 22, 521-525.

90. Al-Mahmood, H.J.; Shatnawi, M.A.; Shibli, R.A.; Makhadmeh, I.M.; Abubaker, S.M.; Shadiadeh, A.N. Clonal propaga-tion and medium-term conservation of Capparis spinosa: A medicinal plant. J. Med. Plants Res. 2012, 6, 3826-3836.

91. Attia, A.; Dessoky, E.D.S.; Al-Sodany, Y.; Ismail, I.A. Ex situ preservation for some endemic and rare medicinal plants in Taif, KSA. Biotechnol. Biotechnol. Equip. 2017, 31, 912-920. [CrossRef]

92. Carra, A.; Sajeva, M.; Abbate, L.; Siragusa, M.; Sottile, F.; Carimi, F. In vitro plant regeneration of caper (Capparis spinosa L.) from floral explants and genetic stability of regenerants. Plant Cell Tissue Organ Cult. 2011, 109, 373-381. [CrossRef]

93. Sottile, F.; Giuggioli, N.R.; Marinoni, D.T.; Peano, C.; Del Signore, M.B. Selection and micropropagation of valuable caper genotypes. Hortic. Sci. 2020, 47, 110-116. [CrossRef] 
94. Gianguzzi, V.; Inglese, P.; Barone, E.; Sottile, F. In Vitro Regeneration of Capparis spinosa L. by Using a Temporary Immersion System. Plants 2019, 8, 177. [CrossRef]

95. Krishna, H.; Alizadeh, M.; Singh, D.; Singh, U.; Chauhan, N.; Eftekhari, M.; Sadh, R.K. Somaclonal variations and their applications in horticultural crops improvement. Biotech 2016, 6, 1-18. [CrossRef]

96. Gianguzzi, V.; Barone, E.; Sottile, A.F. In Vitro Rooting of Capparis spinosa L. as Affected by Genotype and by the Proliferation Method Adopted During the Multiplication Phase. Plants 2020, 9, 398. [CrossRef] 